\title{
Hasil Diagnostik Mycobacterium tuberculosis pada Pasien Batuk $\geq 2$ Minggu dengan Pewarnaan Ziehl Neelsen di Poliklinik Interna RSU Pancaran Kasih Manado
}

\author{
${ }^{1}$ Natasha M. Pomandia \\ ${ }^{2}$ Olivia A. Waworuntu \\ ${ }^{2}$ Heriyannis Homenta
}
${ }^{1}$ Program Studi Pendidikan Dokter Fakultas Kedokteran Universitas Sam Ratulangi Manado
${ }^{2}$ Bagian Mikrobiologi Fakultas Kedokteran Universitas Sam Ratulangi
Email: pomandianatasha@gmail.com

\begin{abstract}
Tuberculosis (TB) is a contagious disease caused by various strains of mycobacteria, commonly Mycobacterium tuberculosis. This disease can occur in children as well as in adults. The most common complaint in TB patients is cough. The gold standard of tuberculosis diagnosis is the culture of TB bacteria. However, Ziehl-Neelsen staining is the most frequently used method. It gives positive result if there are more than $10^{3}$ bacteria per $\mathrm{ml}$ sputum. This study was aimed to find out the existence of $M$. tuberculosis in the sputum of patients coughed $\geq 2$ weeks at the Internal Polyclinic of Pancaran Kasih Hospital Manado by using Ziehl-Neelsen staining. This was a descriptive study using 30 patients as samples. Of 30 samples, all (100\%) had negative results of acid resistant bacili. Conclusion: In this study, all patients with cough $\geq 2$ weeks in the Internal Polyclinic of Pancaran Kasih Hospital Manado had negative results of M. Tuberculosis based on Ziehl-Neelsen staining.
\end{abstract}

Keywords: tuberculosis, cough $\geq 2$ weeks

\begin{abstract}
Abstrak: Tuberkulosis (TB) ialah penyakit menular yang disebabkan oleh berbagai strain mikobakteria, umumnya Mycobacterium tuberculosis. Penyakit ini dapat terjadi pada anak atau orang dewasa. Keluhan yang sering ditemukan pada pasien TB ialah batuk. Dalam menegakkan diagnosis TB, baku emas pemeriksaan ialah kultur kuman TB. Selain kultur dapat digunakan metode pewarnaan basil tahan asam (BTA) Ziehl-Neelsen. Metode ini yang paling sering digunakan dan memberikan hasil positif bila terdapat lebih dari $10^{3} \mathrm{kuman} / \mathrm{ml}$ sputum. Penelitian bertujuan untuk mengetahui ada tidaknya bakteri $M$. tuberculosis dengan menggunakan pewarnaan Ziehl-Neelsen pada pasien dengan batuk $\geq 2$ minggu di Poliklinik Interna RSU Pancaran Kasih Manado. Jenis penelitian ialah deskriptif dengan mengunakan sebanyak 30 sampel. Hasil penelitian mendapatkan pada seluruh sampel (100\%) tidak ditemukan BTA positif. Simpulan: Pada pasien dengan batuk $\geq 2$ minggu di Poliklinik Interna RSU Pancaran Kasih Manado tidak ditemukan BTA positif berdasarkan pewarnaan Ziehl-Neelsen.
\end{abstract}

Kata kunci: tuberkulosis (TBC), batuk $\geq 2$ minggu

Tuberkulosis (TB) adalah penyakit menular yang umum, dan dalam banyak kasus dapat mematikan. Penyakit ini disebabkan oleh berbagai strain mikobakteria, umumnya Mycobacterium tuberculosis. Penyakit TB merupakan penyakit infeksi menular yang banyak didapatkan di negara yang sedang berkembang seperti Indonesia baik pada dewasa maupun anak. ${ }^{1}$ Keluhan yang sering ditemukan pada pasien TB ialah batuk. Batuk adalah pengeluaran sejumlah volume udara secara mendadak dari rongga toraks melalui epiglotis dan mulut. Melalui mekanisme tersebut dihasilkan aliran udara yang sangat 
cepat yang dapat melontarkan keluar material yang ada di sepanjang saluran napas, terutama saluran yang besar. Dengan demikian batuk mempunyai fungsi penting sebagai salah satu mekanisme utama pertahanan respiratorik. ${ }^{2}$

Dalam menegakkan diagnosis TB, sebagai standar baku ialah kultur kuman TB. Selain kultur dapat digunakan metode pewarnaan basil tahan asam (BTA) menurut Ziehl-Neelsen, Tan Thiam Hok, dan Auramin-Phenol Fluorokrom. Metode ZiehlNeelsen yang paling sering digunakan, sederhana tetapi memiliki tingkat sensitivitas serta spesifisitas yang cukup tinggi, yaitu memberikan hasil positif bila terdapat lebih dari $10^{3} \mathrm{kuman} / \mathrm{ml}$ sputum. Metode fluorokrom memiliki sensitivitas yang lebih tinggi, tetapi memiliki kelemahan yaitu memerlukan peralatan yang mahal. ${ }^{3}$

Prevalensi TB di Indonesia masih tinggi dan menempati urutan ke-3 di dunia setelah China dan India. ${ }^{4}$ Data World Health Organization (WHO) pada tahun 2015, melaporkan sebanyak 10,4 juta orang mengidap TB dan 1,8 juta meninggal karena penyakit ini (termasuk 0,4 juta di antara orang dengan HIV-AIDS). Lebih dari 95\% kematian TB terjadi di negara berpenghasilan rendah dan menengah. ${ }^{5}$ Pada tahun yang sama data dari Pusat Data dan Informasi Kementerian Kesehatan RI melaporkan sebanyak kurang lebih 190 ribu kasus disumbang oleh kasus dengan BTA positif. ${ }^{6}$ Mengenai angka kejadian kasus TB, Manado merupakan kota teratas dalam kasus TB Paru sebanyak 1358 kasus dari total sebanyak 5242 kasus yang ada di Provinsi Sulawesi Utara. Penderita TB pada laki-laki lebih banyak 1,5 dibandingkan pada perempuan, dan 4 kali lebih tinggi pada masyarakat berpendidikan rendah dibandingkan yang berpendidikan tinggi. Rentang usia TB pada kasus kontak ialah 28-46 tahun pada laki-laki dan 20-56 tahun pada perempuan.,

\section{METODE PENELITIAN}

Jenis penelitian ini ialah deskriptif. Subyek penelitian ialah pasien dengan batuk $\geq 2$ minggu di poliklinik Interna RSU Pancaran Kasih Manado dengan selang waktu antara bulan Agustus-November 2017.

Pengambilan sputum sesuai dengan pemeriksaan dahak sewaktu-pagi-sewaktu kemudian sampel sputum yang diperoleh diproses dengan pewarnaan Ziehl-Neelsen dan diperiksa menggunakan mikroskop pembesaran 1000x.

\section{HASIL PENELITIAN}

Berdasarkan penelitian yang telah di lakukan di Poliklinik Interna RSU Pancaran Kasih Manado dengan selang waktu antara bulan Agustus-November 2017 didapatkan sebanyak 30 sampel pasien dengan keluhan batuk $\geq 2$ minggu.

Pada pasien dengan batuk $\geq 2$ minggu didapatkan 22 orang berjenis kelamin lakilaki $(73 \%)$ dan 8 orang berjenis kelamin perempuan (27\%) (Tabel 1).

Tabel 1. Distribusi pasien dengan batuk $\geq 2$ minggu berdasarkan jenis kelamin

\begin{tabular}{lcc}
\hline Jenis kelamin & Jumlah & Persentase \\
\hline Laki laki & 22 & $73 \%$ \\
Perempuan & 8 & $27 \%$ \\
Total & 30 & $100 \%$ \\
\hline
\end{tabular}

Berdasarkan kelompok usia, pasien dengan batuk $\geq 2$ minggu paling banyak ditemukan pada kelompok usia 15-24 tahun (27\%) (Tabel 2).

Tabel 2. Distribusi pasien batuk $\geq 2$ minggu berdasarkan kelompok usia

\begin{tabular}{lcc}
\hline \multicolumn{1}{c}{ Usia } & Jumlah & Persentase \\
\hline $15-24$ tahun & 8 & $27 \%$ \\
$25-34$ tahun & 4 & $13 \%$ \\
$35-44$ tahun & 4 & $13 \%$ \\
$45-54$ tahun & 3 & $10 \%$ \\
$55-64$ tahun & 5 & $17 \%$ \\
$>65$ tahun & 6 & $20 \%$ \\
Total & 30 & $100 \%$ \\
\hline
\end{tabular}

Berdasarkan hasil pemeriksaan sputum menggunakan metode Ziehl-Neelsen pada pasien dengan batuk $\geq 2$ minggu didapatkan sebanyak 30 kasus (100\%) dengan BTA (-); tidak terdapat kasus dengan BTA (+) (Tabel 3). 
Tabel 3. Penderita batuk $\geq 2$ minggu berdasarkan hasil pemeriksaan BTA

\begin{tabular}{ccc}
\hline $\begin{array}{c}\text { Hasil } \\
\text { Pemeriksaan }\end{array}$ & Jumlah & Persentase \\
\hline BTA (+) & 0 & 0 \\
BTA (-) & 30 & $100 \%$ \\
Total & 30 & $100 \%$ \\
\hline
\end{tabular}

\section{BAHASAN}

Penelitian ini bertujuan untuk mengetahui hasil diagnostik $M$. tuberculosis menggunakan metode pewarnann Ziehl-Neelsen dari sampel sputum pasien dengan keluhan batuk selama $\geq 2$ minggu di RSU Pancaran Kasih Manado. Penelitian ini dilakukan selama rentang waktu dari bulan Agustus-November dan mendapatkan sebanyak 30 sampel dengan keluhan batuk $\geq 2$ minggu. Angka kejadian pada laki-laki (73\%), lebih besar dibandingkan pada perempuan $(27 \%)$.

Kejadian dengan keluhan batuk $\geq 2$ minggu selaras dengan yang dilaporkan oleh Hiswani $^{8}$ yakni dalam 1 tahun kejadian penyakit ini lebih tinggi pada laki-laki dibandingkan dengan perempuan. Hal ini dapat disebabkan karena laki-laki pada umumnya sering merokok dan minum alkohol sehingga dapat menurunkan sistem ketahanan tubuh yang pada akhirnya lebih rentan dan lebih mudah menderita batuk $\geq 2$ minggu. Merokok dapat menyebabkan kerusakan sel epitel dan silia pada saluran napas, sehingga bila seseorang terpapar dengan agen penyebab TB paru, maka dengan mudah terjadi infeksi TB.

Penelitian yang dilakukan Herryanto et al. ${ }^{9}$ mendapatkan proporsi pengidap TB paru lebih besar pada laki-laki $(54,5 \%)$ dibandingkan perempuan $(45,5 \%) .{ }^{8,9}$ Hasil ini sangat tidak sejalan dengan penelitian yang dilakukan oleh Dotulong et al. ${ }^{10}$ di Kecamatan Wori Manado pada tahun yang sama yang mendapatkan sebanyak 59,8\% kasus pada perempuan dan 40,2\% pada lakilaki.

Pada Tabel 4 dilaporkan sebanyak 27\% kasus pasien dengan batuk $\geq 2$ minggu pada kelompok usia 15-24 tahun yakni pada usia produktif. Hasil penelitian ini sesuai dengan data TB di Indonesia yaitu sebagian besar pasien TB tergolong pada usia produktif, dengan rentang usia 15-55 tahun. ${ }^{11}$ Hasil penelitian ini juga sejalan dengan pernyataan dari DEPKES RI bahwa sekitar 75\% kasus TB ialah kelompok usia produktif secara ekonomis. Hal ini dapat terjadi karena usia produktif lebih sering melakukan kegiatan dan juga akan mencoba berbagai hal baru. Seseorang yang melakukan banyak aktivitas akan lebih sering berhadapan langsung dan berinteraksi dengan orang-orang baru, sehingga dapat meningkatkan kemungkinan terjadinya penularan TB. ${ }^{12}$

Distribusi hasil pemeriksaan BTA pada pasien dengan keluhan batuk $\geq 2$ minggu di RSU Pancaran Kasih Manado menunjukkan hasil yaitu tidak ditemukan BTA positif, tetapi menunjukkan hasil negatif sebanyak 30 kasus dengan persentase $100 \%$. Penelitian yang dilakukan Sondak et al. ${ }^{13}$ di Puskesmas Paniki bawah, Tikala baru, dan Wonasa Manado melaoprkan bahwa hasil pemeriksaan BTA pada pasien dengan batuk $\geq 2$ minggu di Puskesmas Paniki ditemukan 2 pasien (11,76 \%) positif dan 15 pasien (88,24\%) negatif; di Puskesmas Tikala Baru ditemukan 1 pasien $(7,69 \%)$ positif dan 12 pasien (92,31 \%) negatif; dan di Puskesmas Wonasa tidak ditemukan BTA positif. Hal ini dapat disebabkan karena adanya kebijakan dari Pemerintah Republik Indonesia dalam hal ini Kementerian Kesehatan dan BUMN BPJS yang mengharuskan setiap penduduk Indonesia harus terdaftar sebagai anggota BPJS. Setiap pasien yang berobat harus dari dokter keluarga atau fasilitas kesehatan tingkat pertama (FKTP) untuk mendapat pelayanan dan penanganan. Pasien dapat dirujuk ke fasilitas pelayanan sekunder dan tersier bila tidak dapat ditangani di FKTP. Diduga pasien dengan keluhan batuk $\geq 2$ minggu telah mendapat pemeriksaan dan penanganan yang baik di FKTP sehingga tidak ada rujukan ke fasilitas kesehatan selanjutnya, antara lain di tempat penelitian yaitu RSU Pancaran Kasih Manado. Selain itu, semua pasien yang telah didiagnosis TB di FKTP akan mendapat terapi OAT secara gratis dari pemerintah, dan didukung juga adanya kesadaran dari pasien untuk minum obat secara teratur. 


\section{SIMPULAN}

Dari hasil penelitian ini dapat disimpulkan bahwa jenis kelamin laki-laki dan kelompok usia 15-24 tahun yang terbanyak menderita batuk $\geq 2$ minggu dengan keseluruhan hasil pemeriksaan sputum yang negatif BTA.

\section{DAFTAR PUSTAKA}

1. Hapsari AR, Farida F, Balwaa F, Saraswati L. Analisis kaitan merokok terhadap pasien tuberkulosis paru di Puskesmas Srondol. Jurnal Ilmiah Mahasiswa. 2013;3:48.

2. Setyano DB. Batuk kronik pada anak: Masalah dan tatalaksana. 2004. [cited 2017 Aug 20]. Available from: saripediatri.idai.or.id/ pdfile/6-2-2.

3. Muzaffar R, Batool S, Azis A, Naqvi A, Rizvi A. Evaluation of the FASTPLAQUETB assay for direct detetction of Mycobacterium tuberculosis in sputum specimens. Int $\mathbf{J}$ Tuberc Lung Dis. 2002;6(7):635-40.

4. Jawetz, Melnick, Adelberg. Mikobakterium. In: Brooks GF, Butel JS, Morse SA, penyunting. Mikrobiologi Kedokteran (23nd ed). Jakarta: Penerbit Buku Kedokteran FKUI, 2008; p. 325.

5. World Health Organization. 10 facts of tuberculosis. March 2017. [cited 2017 Aug 30]. Available from: http://www.who.int/ features/factfiles/tuberculosis/en/\#.

6. Pusat Data dan Informasi Kementrian
Kesehatan RI. Data dan Informasi 2016 "Profil Kesehatan Indonesia". Mei 2016.

7. Badan Pusat Statistik Provinsi Sulawesi Utara. Sulawesi Utara Dalam Angka 2015. 2015

8. Hiswani. Tuberculosis merupakan penyakit infeksi yang masih menjadi masalah kesehatan masyarakat. Available from: http://library.usu.ac.id/download/fkmhiswani6.pdf2009

9. Herryanto D, Musadad A, Komalig FM. Riwayat pengobatan penderita TB paru meninggal di Kabupaten Bandung. Jurnal Ekologi Kesehatan. 2004;3(1):1-6.

10. Dotulong JF, Sapulete MR, Kandou GD. Hubungan faktor risiko umur, jenis kelamin dan kepadatan hunian dengan kejadian TB Paru di Desa Wori Kecamatan Wori. Jurnal Kedokteran Komunitas dan Tropik. 2015;III(2):57-65.

11. TB Indonesia. Available from: www. tbindonesia.or.id/epidem-tb-indonesia/

12. Ihram MA. Hubungan tingkat sirkulasi oksigen dan karakteristik individu dengan kejadian TB Paru pada kelompok usia produktif di Puskesmas Pondok Pucung tahun 2013 [Skripsi]. Jakarta: UIN Syarif Ihdayatullah; 2013.

13. Sondak M, Porotuo J, Homenta H. Hasil diagnostik Mycobacterium tuberculosis dari sputum penderita batuk $\geq 2$ minggun dengan pewarnaan Ziehl-Neelsen di Puskesmas Paniki Bawah, Tikala Baru dan Wonasa Manado. eBm. 2016;4(1). 